\title{
Do VDR Gene Polymorphisms Contribute to Breast Cancer?
}

\author{
Fouzia Shaikh*, Saeeda Baig, Qamar Jamal
}

\begin{abstract}
Breast cancer is the first or second leading cancer among females across the globe. A large number of studies have been conducted to assess any relationship between vitamin D receptor (VDR) gene polymorphisms and breast cancer development. Epidemiological studies have indicated that ethnic traits exhibited by a group of people with a common ancestry and culture, alter the link between VDR gene and breast cancer. It has been hypothesized that VDR polymorphisms have the capacity to impact both on incidence of breast cancer occurrence and to predict its outcome. A survey was here conducted to assess and compare the impact of vitamin D receptor gene polymorphisms Fok1, Bsm1, Taq1, Apa1 and poly (A) on development of breast cancer. Information was obtained from electronic databases including PubMed and Google Scholar for articles published during the period from 1996 to 2015. This search was achieved by using the terms "genetics", "breast cancer", "VDR gene", "polymorphisms". However, due to inconsistent results, no conclusive statements could be presented about the significance of the VDR genotype as far as the development of breast carcinoma is concerned'
\end{abstract}

Keywords: Breast cancer - VDR gene - polymorphisms - impact on development

Asian Pac J Cancer Prev, 17 (2), 479-483

\section{Introduction}

Breast cancer stands the second most leading cancer among females around the globe (Du et al., 2014). It is the most frequently diagnosed cancer in Pakistan, with highest mortality rate in Asian population after the Jews from Israel. Karachi, has the maximum rate of breast carcinoma $(38 \%)$ in female among the registered cancer cases (Iqbal $\mathrm{MuN}, 2015)$. The incidence rate of carcinoma of breast is comparable with highest risk regions in the world (Bhurgri et al., 2006). The overall risk of developing carcinoma of breast makes it the most frequent malignancy among the white females with estimates of 1 in 12 British and 1 in 8 American women (Khan et al., 2014).

The risk of breast cancer has been evaluated in relation to vitamin $\mathrm{D}$ receptor gene polymorphisms in number of studies because of evidence of regulatory effects on angiogenesis in malignancy (Banerjee, 2003; Giovannucci, 2005). The VDR was discovered in 1969 (Norman, 2008). Discovery of VDR expression in diverse normal human tissues cells has widened the perceived scope of the vitamin D. Vitamin D endocrine system is involved in several processes besides bone formation, like innate immunity, apoptosis, cell proliferation and differentiation, and mediates the anticancer activities of vitamin D via the Vitamin D Receptor (VDR) (Raimondi et al., 2009).

Female breast cancer occurrence is strongly age related, suggesting a link with hormonal status. Contrary to international studies, Pakistani women between 20 to 35 years of age are frequently reported in Karachi hospitals with advanced stages of breast cancer with large lesions, and are prone to develop metastasis with bad prognosis (Bhurgri et al., 2006; Naveed et al., 2014). In the UK between the years 2009 and 2011, approximately $80 \%$ of breast cancer cases were diagnosed above the age of 50 years, and about $24 \%$ in women aged 75 years and above, based on Breast cancer incidence statistics (2013).

The objectives of this search were to determine the effect of polymorphisms of the frequent SNPs in VDR (Fok1, Bsm1, Taq1, Apa1, Poly A) and the evolution of the breast carcinoma.

\section{Discussion}

Breast carcinoma is the cumulative result of various environmental and genetic alterations. Mechanism of breast cancer development is still not well established, but published data has identified the anti-cancerous functions of 1, $25(\mathrm{OH}) 2$ vitamin D3 in some malignancies (Iqbal MuN, 2015).

VDR Receptors in Mammary Glands: The calcitriol receptor also known as vitamin D receptor (VDR) is an intracellular hormone receptor, and a member of the nuclear class II receptor family of broadly known two groups and peculiarly binds to biologically effective form of vitamin D, 1,25-dihydroxyvitamin D (Raimondi et al., 2009). One family comprises of the estrogen, androgen, progesterone and mineralocorticoid receptors, while the other has thyroid (THR), vitamin D (VDR), retinoic acid (RAR), peroxisome proliferator-activated, and retinoid $\mathrm{X}$ receptors (RXR) (Ditsch et al., 2012). More than 36 
types of tissue in the body have expression of Vitamin D Receptor like breast, bone, prostate, gut, activated B and $\mathrm{T}$ lymphocytes, monocytes, and keratinocytes with distinct mitochondrial, membrane, cytosol and perinuclear localization (Gombart, 2006; Silvagno et al., 2010). In normal mammary gland VDR is expressed in epithelial, stromal, and immune cells and is controlled in the epithelial compartment during hormonal changes during puberty and pregnancy (Zinser, 2004). Figure1

Several studies show that genetic variance can affect an individual receptivity to dietary or pharmacological interventions (Welsh, 2007). SNPs are widely dispersed through the human genome and because of great levels of inconsistency, have gained reputation as genetic markers helpful in attaining disease vulnerability in complicated genetic characteristics (Collins et al., 1997).

VDR Gene and Breast Cancer: The molecular location of VDR receptor gene is on the long arm of chromosome 12 (12q12-q14) and includes not less than 11 exons that stretch $60 \mathrm{~kb}$ of DNA with five promoter regions (Zhou, 2009). Figure 2

VDR Genotypes and Polymorphisms: VDR gene has more than 470 single-nucleotide polymorphisms (SNPs) (Zmuda et al., 2000; Mc Cullough et al., 2009). The important and intensively studied single nucleotide polymorphisms (SNPs) of VDR are, FokI (rs2228570), VDR-BsmI (rs1544410), VDR-TaqI (rs731236), VDRApaI (rs7975232) and Poly(A) (Alimirah et al., 2011). Over the years, most of The molecular epidemiological studies have been done to relate the associations of important VDR polymorphisms with breast cancer (Curran et al., 1999; Ingles et al., 2000; Bretherton et al., 2001; Hou et al., 2002; Buyru et al., 2003; Guy et al., 2004; Sillanpaa et al., 2004; Chen et al., 2005; Lowe et al., 2005; John et al., 2007; Mc Cullough et al., 2007; Trabert et al., 2007; Abbas et al., 2008; Barroso et al., 2008; Sinotte et al., 2008; Chakraborty et al., 2009; McKay et al., 2009; Rollison et al., 2011; Huang et al., 2012; Mishra et al., 2013; Du et al., 2014

Ethnic Variation in VDR Gene Polymorphisms: VDR gene show sequence level dissimilarity in the different populations, both at the 5' and 3' termini (Trabert et al., 2007). Epidemiological studies have frequently reported that the fundamental features of the population with varying ethnicities can alter the links between VDR gene polymorphisms and carcinoma. The ethnic groups were categorized into (Caucasian, Asian, and AfricanAmerican) by Wang et al., 2013. Review by Uitterlinden AG et al. (2004) and Kostner et al. (2009) showing ethnic variation. Indian subcontinent where populations/ethnicity are quite different, not much information regarding the allelic variations of VDR (Fok1) gene is available (Bid, 2003). Figure 3

The VDR gene FokI polymorphism and breast cancer risk: The Fork1 restriction enzyme occupies a polymorphic site in exon 2 of the VDR gene (Yang B et al., 2014). Genotypes are identified as FF, Ff and ff for the VDR-FokI polymorphisms. The capital letter indicates the absence and small letter the existence of the restriction site (Uitterlinden et al., 2004). The alliance of Fok1 polymorphism with breast cancer reveals that Fok 1 is the most controversial SNP. VDR FF allele in combination with long-Poly A was reported to be a possible risk factor in the UK in the study by Guy et al. (2004), whereas Chen et al (2005) found VDR ff to be a risk factor in the Nurses' Health study in the USA. In the year 2009, the meta-analysis was done by Tang et al, which shows a strong connection between VDR ff and raised risk of breast cancer in European females. Study by Shahbazi et al. (2013) on Iranian breast cancer patients could not establish statistically significant affiliation between Fok1 genotypes and breast carcinoma. However in 2013, Mishra et al, proposed that VDR FokI $\mathrm{f}$ allele may share in the evolution of breast carcinoma in young age and $\mathrm{F}$ allele in tumor progression and patient prognosis.

The VDR gene BsmI polymorphism and breast cancer risk: The Bsm1 polymorphism is situated at the 3' end of the VDR gene. It does not affect the quality of the translated VDR protein (Raimondi Set al., 2009). Genotypes assigned are $\mathrm{BB}, \mathrm{Bb}$, bb for the BsmI polymorphisms. The second most frequent studied VDR polymorphism-BsmI, which after analysis showed mixed results. Some studies reported its association with breast cancer development (Guy et al., 2004; Shahbazi et al., 2013).The study by Lowe et al. (2005) shows strong association between the VDR bb genotype and breast cancer. Studies by other researchers did not reveal any significant difference in the prevalence of the BsmI polymorphism in breast cancer patients (Chen et al., 2005;

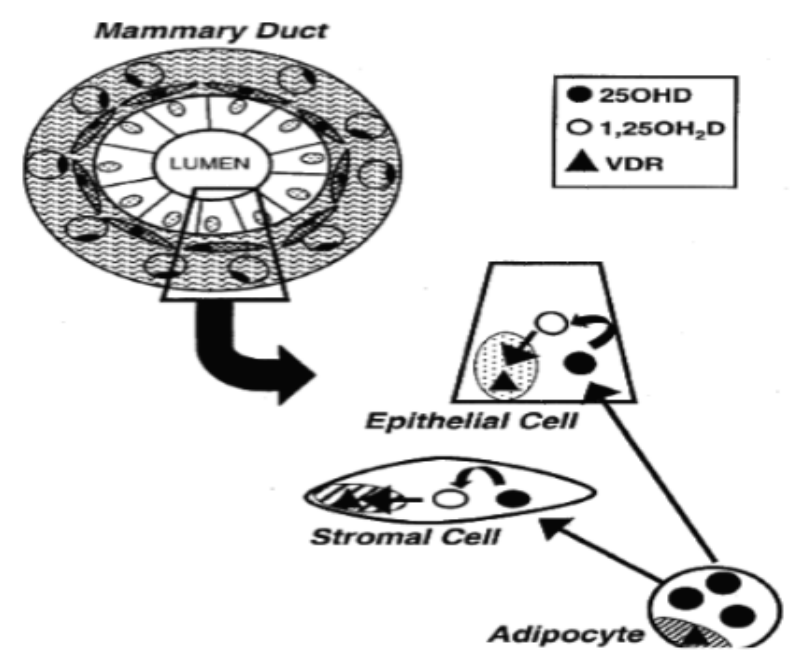

Figure 1. Localization of VDR in Mammary Gland

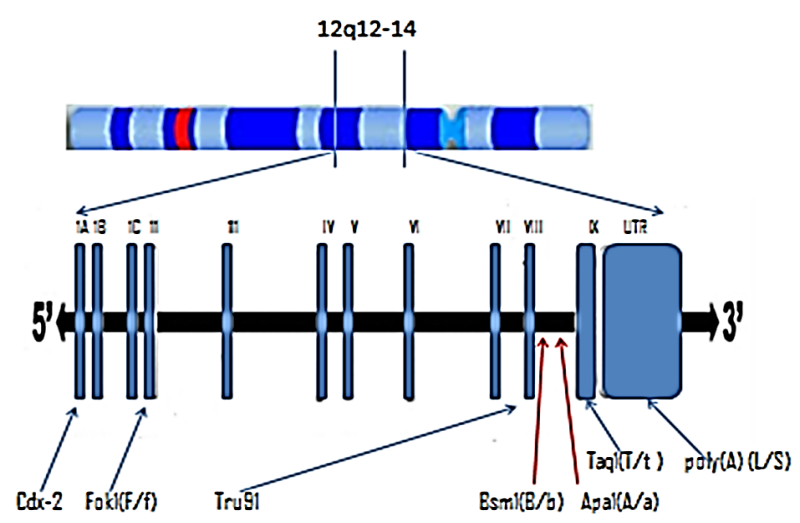

Figure 2. Human Vitamin D Receptor (VDR) Gene Polymorphic Sites 
Wang et al., 2013; Zhang, 2014).

The VDR gene ApaI polymorphism and breast cancer risk: Apa1 restriction sites lies in an intronic region between exon VII and IX (Buyru N et al., 2003). Genotypes were designated as AA, Aa, aa for the ApaI polymorphisms. VDR Apalpolymorphisms were identified to have significant association with tumor differentiation. Anaplastic tumors are more inclined to express a polymorphic allele of VDR ApaI (Aa or aa). Alleles of VDR, ApaI confer an increased risk for breast cancer development in few studies (Guy et al., 2004; Engel et al., 2013; Fuhrman et al., 2013) ,but data from

VDR Gene Polymorphism

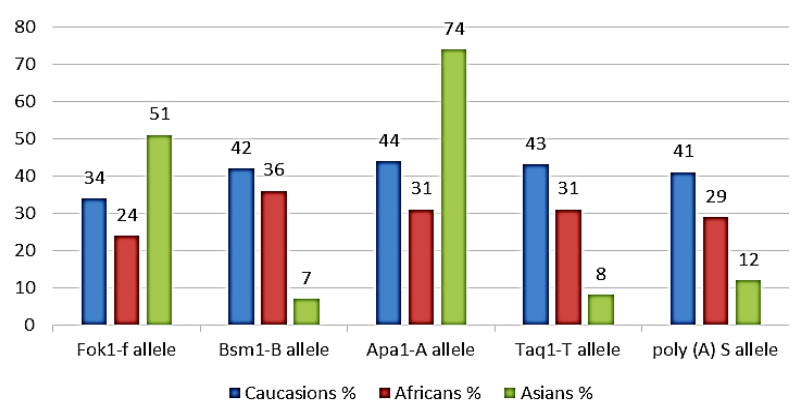

Figure 3. Ethnic Variation in VDR Gene Polymorphisms (after Kostner, 2009; Uitterlinden et al, 2004
DOI:http://dx.doi.org/10.7314/APJCP.2016.17.2.479 Do VDR Gene Polymorphisms Contribute to Breast Cancer? various other researches showed no associations between the VDR variants ApaI and breast cancer (Hou et al., 2002; Bhanushali et al., 2009; Chakraborty et al., 2009; Dalessandri et al., 2011; Mishra et ai., 2013).

VDR gene TaqI po lymorphism and breast cancer risk: The TaqI polymorphism is a T/C nucleotide substitution (ATT to ATC), an RFLP at codon 352 in exon 9 of the VDR gene. Individuals are generally designated as TT, Tt or tt. Taq1 shows a definite association with breast cancer in few researches. Study by Perna L et al (2013), points to a significant prognostic value of taqlin breast cancer patients. No significant increase in risk for breast cancer has been seen in women both heterozygous and homozygous for $\mathrm{t}$ allele in multiple studies (Wang et al., 2013).

The VDR gene poly(A) polymorphism and breast cancer risk: The poly (A) mononucleotide repeat occupies the 3'-untranslated region (3'-UTR) section of the gene, firmly interconnected with Bsm1, Apa1 and Taq1 has a strong influence on VDR mRNA integrity (Gombart, 2006). Individuals are categorized as having alleles with short (S, with $<18 \mathrm{As}$ ) or long (L, with $>18 \mathrm{As}$ ) poly (A) stretches. The $\mathrm{S}$ allele is considered to be the more effective VDR allele (Mishra et al., 2013).

Vitamin D receptor (VDR) poly (A), polymorphism has been implicated in the development of breast

Table 1. Analyses of Polymorphisms in Breast Cancer

\begin{tabular}{|c|c|c|c|c|c|}
\hline Studies & Year & Polymorphism & Study Type & Study Population & Cases/Controls \\
\hline Abbas et al & 2008 & Fok1, Taq1 & PCCS* & German & $1408 / 2612$ \\
\hline Barroso et al & 2008 & Fok1,Taq1 & $\mathrm{CCS} * *$ & Spanish & $549 / 556$ \\
\hline Bretherton-Watt et al & 2001 & Fok1, Bsm1 & $\mathrm{CCS}$ & Caucasian & $181 / 241$ \\
\hline Buyru et al & 2003 & Bsm1, Taq1 & $\mathrm{CCS}$ & Turkish & $78 / 27$ \\
\hline Chakraborty et al & 2009 & Apa1, Taq1 & CCS & North Indian & $160 / 140$ \\
\hline Chen et al & 2005 & Fok1, Bsm1 & $\mathrm{CCS}$ & USA & $1234 / 1676$ \\
\hline Curran et al & 1999 & Fok1, Taq1, Apa1 & $\mathrm{CCS}$ & Australian & $135 / 110$ \\
\hline Fuhrman et al & 2013 & Fok1, Bsm1 & CCS & USA & $484 / 845$ \\
\hline Guy et al & 2004 & Fok1, Bsm1, poly(A) & $\mathrm{CCS}$ & Caucasian & $398 / 427$ \\
\hline Hou et al & 2002 & ApaI, TaqI, and BsmI & $\mathrm{CCS}$ & Taiwanese & $80 / 169$ \\
\hline Huang et al & 2012 & Bsm1, Apa1, Taq1 & $\mathrm{CCS}$ & Han Chinese & $146 / 320$ \\
\hline Ingles et al & 2000 & Fok1, Bsm1 & $\mathrm{CCS}$ & Latinas & $143 / 300$ \\
\hline John et al & 2007 & Fok1, Taq1, Bgl1 & $\mathrm{CCS}$ & Mixed & $814 / 910$ \\
\hline Lowe et al & 2005 & Bsm1 & $\mathrm{CCs}$ & Caucasian & $179 / 179$ \\
\hline MacKay & 2008 & Fok1, Bsm1 & $\mathrm{CCS}$ & Caucasian & $6300 / 8100$ \\
\hline McCullough et al & 2007 & $\begin{array}{l}\text { Fok1, Bsm1, Taq1, Apa1, poly } \\
\text { (A) }\end{array}$ & $\mathrm{NCCS} * * *$ & Caucasian & $500 / 500$ \\
\hline Mishra DK et al & 2013 & Fok1, Bsm1, Taq1, Apa1 & $\mathrm{CCS}$ & Mixed & $232 / 349$ \\
\hline Rollison et al & 2012 & Fok1, Bsm1 & PCCS & Hispanic, non-Hispanic & $2,325 / 2,525$ \\
\hline Sillanpaa et al & 2004 & Apa1, Taq1 & CCS & Finnish & $483 / 482$ \\
\hline Sinotteet al & 2007 & Fok1,Bsm1 & $\mathrm{CCS}$ & French Canadian & $718 / 1596$ \\
\hline Trabert et al & 2007 & Bsm 1 & PCCS & $\begin{array}{c}\text { Caucasian\& African } \\
\text { American }\end{array}$ & $1631 / 1435$ \\
\hline Yang et al & 2014 & Fok1, Bsm1, Apa1 and Taq1 & $\mathrm{CCS}$ & Caucasian & $38,151 / 47,546$ \\
\hline Yingying Du & 2014 & Bsm1 & CCS & Mixed & $10,212 / 12,808$ \\
\hline
\end{tabular}

*Population-based case-control study; **Case-Control study; ***Nested Case-Control Study 


\section{Fouzia Shaikh et al}

carcinoma. In 2000, Ingles et al, reported a remarkably elevated probability of breast malignancy among Latina females of different cultural groups with the SS genotype as compared to the LL poly (A). However, meta-analysis of studies by Jinjiang et al. (2014) showed no interconnection of VDR poly (A) polymorphism with chance of developing breast cancer.

\section{Conclusion}

Insight into the role of VDR polymorphisms imparts idealistic vision or perception which can expedite the development of up to date prophylactic approaches for breast malignancies.

The evaluation of data regarding the VDR gene polymorphisms, most prevalent in breast carcinoma of various ethnic populations shows diverse results. This might be due to the limitation of individual studies or genetic variations due to racial or cultural diversity.

\section{Acknowledgements}

\section{Grant Support \& Financial Disclosures: None}

\section{References}

Abbas S, Nieters A, Linseisen J, et al (2008). Vitamin D receptor gene polymorphisms and haplotypes and postmenopausal breast cancer risk. Breast Cancer Res, 10, 31 .

Alimirah F, Peng X, Murillo G, et al (2011). Functional significance of vitamin $\mathrm{D}$ receptor FokI polymorphism in human breast cancer cells. PLoS One, 6, 16024.

Banerjee P, Chatterjee M (2003). Antiproliferative role of vitamin D and its analogs - a brief overview. Mol Cell Biochem, 253, 247-54.

Barroso E, Fernandez LP, Milne RL, et al (2008). Genetic analysis of the vitamin D receptor gene in two epithelial cancers: melanoma and breast cancer case-control studies. BMC Cancer, 8,385

Bhanushali AA, Lajpal N, Das BR, et al (2009). Frequency of fokI and taqI polymorphism of vitamin $D$ receptor gene in Indian population and its association with 25 hydroxyvitamin D levels. Indian J Hum Genet, 15, 108-113.

Bhurgri Y, Bhurgri A, Nishter S, et al (2006). Pakistan - country profile of cancer and cancer control, 1995-2004. J Pak Med Assoc, 56, 124-30.

Bid H K, Mittal R D (2003). Study of vitamin-D receptor (VDR) gene start codon polymorphism (Fok I) in healthy individuals from North India. Indian J Hum Genet, 9, 51-4.

Breast cancer incidence statistics I Cancer Research UK [Online]. Bretherton WD, Given WR, Mansi JL, et al (2001). Vitamin $\mathrm{D}$ receptor gene polymorphisms are associated with breast cancer risk in a UK Caucasian population. Br J Cancer, 85, 171-5.

Buyru N, Tezol A, Yosunkaya-Fenerci E, et al (2003). Vitamin $\mathrm{D}$ receptor gene polymorphisms in breast cancer. Exp Mol Med, 35, 550-5.

Chakraborty A, Mishra AK, Soni A, et al (2009). Vitamin D receptor gene polymorphism(s) and breast cancer risk in north Indians. Cancer Detect Prev, 32, 386-94.

Chen WY, Bertone-Johnson ER., Hunter DJ, et al (2005). Associations between polymorphisms in the vitamin D receptor and breast cancer risk. Cancer Epidemiol. Biomarkers Prev, 14, 2335-9.

Collins ES, Guyer MS, Chakravarti A, et al (1997). Variations on a theme; cataloging human DNA sequence variation. Science, 278, 1580-1.

Curran JE, Vaughan T, Lea RA, et al (1999). Association of A vitamin $\mathrm{D}$ receptor polymorphism with sporadic breast cancer development. Int J Cancer, 83, 723-726.

Dalessandri KM, Mike R, Wiencke JK, et al (2011). Vitamin D receptor polymorphisms and breast cancer risk in a highincidence population: a pilot study. J Am Coll Surg, 215, 652-7.

Ditsch N, Toth B, Mayr D, et al (2012). The Association between Vitamin D Receptor Expression and Prolonged Overall Survival in Breast Cancer. Journal of Histochemistry \& Cytochemistry, 60(2), 121-129

$\mathrm{Du}$ Y, Hu L, Kong F, et al (2014). Lack of association between vitamin D receptor gene BsmI polymorphism and breast cancer risk: an updated meta-analysis involving 23,020 subjects. Tumor Biol, 35, 2087-93.

Engel LS, Orlow I, Sima CS, et al (2012). Vitamin D receptor gene haplotypes and polymorphisms and risk of breast cancer: a nested case-control study. Cancer Epidemiol Biomarkers Prev, 21, 1856-67.

Fuhrman BJ, Freedman DM, Bhatti P, et al (2013). Sunlight, Polymorphisms of Vitamin D-related Genes and Risk of Breast Cancer. Anticancer Res, 33, 543-51.

Giovannucci E (2005). The epidemiology of vitamin D and cancer incidence and mortality: a review. Cancer Causes Control, 16, 83-95.

Gombart AF, Luong QT, Koeffler HP, et al (2006). Vitamin D compounds activity against microbes and cancer. Anticancer Res, 26, 2531-42.

Guy M, Lowe LC, Bretherton-Watt D, et al (2004). Vitamin D receptor gene polymorphisms and breast cancer risk. Clin Cancer Res, 10, 5472-81.

Hou MF, Tien YC, Lin GT, et al (2002). Association of vitamin $D$ receptor gene polymorphism with sporadic breast cancer in Taiwanese patients. Breast Cancer Res Treat, 74, 1-7.

Huang YZ, Lu H, Bai YH, et al (2012). Relationship between genotypes and halpotypes of vitamin $\mathrm{d}$ receptor gene and breast cancer risk. J Med Res, 41, 89-92.

Ingles SA, Garcia DG, Wang W, et al (2000). Vitamin D receptor genotype and breast cancer in Latinas (United States). Cancer Causes Control, 11, 25-30.

Iqbal MuN, Khan TA, Maqbool SA (2015). Vitamin d receptor cdx-2 polymorphism and premenopausal breast cancer risk in southern pakistani patients. PLOS ONE, 10, 122657.

Jinjiang Xu, Hongyu Li , Lixue Gu, et al (2014). Association between vitamin D receptor poly(A) polymorphism and breast cancer risk: a meta-analysis. Tumor Biol, 35, 589-93.

John EM, Schwartz GG, Koo J, et al (2007). Sun exposure, vitamin $\mathrm{D}$ receptor gene polymorphisms, and breast cancer risk in a multiethnic population. Am J Epidemiol, 166, 1409-19.

Khan MI, Bielecka FZ, Najm ZM, et al (2014). Vitamin D receptor gene polymorphisms in breast and renal cancer. current state and future approaches (Review). Int J Oncol, 44, 349-63.

Kostner K, Denzeri N, Cornelia SL, et al (2009). The relevance of vitamin $\mathrm{D}$ receptor (VDR) gene polymorphisms for cancer: a review of the literature. Anticancer Res, 29, 3511-36.

Lowe LC, Guy M, Mansi JL, et al (2005). Plasma 25-hydroxy vitamin D concentrations, vitamin D receptor genotype and breast cancer risk in a UK Caucasian population. Eur J Cancer, 41, 1164-9.

McCullough ML, Bostick RM, Mayo TL, et al (2009). Vitamin D gene pathway polymorphisms and risk of colorectal, breast, and prostate cancer. Annu Rev Nutr, 29, 111-32.

McKay JD, Mc Cullough ML, Ziegler RG, et al (2009). Vitamin 
$\mathrm{d}$ receptor polymorphisms and breast cancer risk: results from the national cancer institute breast and prostate cancer cohort consortium. Cancer Epidemio Biomarkers Prev, 18, 297-305.

Mishra DK, Wu Y, Sarkissyan M, et al (2013). Vitamin d receptor gene polymorphisms and prognosis of breast cancer among african-american and hispanic women. PLOS ONE, 8, 57967.

Naveed S, Kamal A, Shamshad D, et al (2014). Frequency and Risk Factors of Breast Cancer in Karachi, Pakistan. Int J Med Sciences (DHR-IJMS), 5, 52-60.

Norman AW (2008). From vitamin D to hormone D: fundamentals of the vitamin D endocrine system essential for good health. Am J Clin Nutr, 88, 491-9.

Perna L, Butterbach K, Haug U, et al (2013). Vitamin D receptor genotype rs731236 (Taq1) and breast cancer prognosis. Cancer Epidemiol Biomarkers Prev, 22, 437-42.

Raimondi S, Johansson H1, Maisonneuve P, et al (2009). Review and meta-analysis on vitamin D receptor polymorphisms and cancer risk. Carcinogenesis, 30, 1170-80.

Rollison DE, Cole AL, Tung KH, et al (2011). Vitamin D intake,vitamin $\mathrm{D}$ receptor polymorphisms, and breast cancer risk among women living in the southwestern U.S. Breast Cancer Res Treat, 132, 683-91.

Shahbazi S, Alavi S, Majidzadeh A K, et al (2013). BsmI but not FokI polymorphism of VDR gene is contributed in breast cancer. Med Oncol, 30, 393.

Sillanpaa P, Hirvonen A, Kataja V, et al (2004). Vitamin D receptor gene polymorphism as an important modifier of positive family history related breast cancer risk. Pharmacogenetics, 14, 239-45.

Silvagno F, De Vivo E, Attanasio A, et al (2010). Mitochondrial localization of vitamin D receptor in human platelets and differentiated megakaryocytes. PLOS ONE, 5, 8670.

Sinotte M, Rousseau F, Ayotte P, et al (2008). Vitamin D receptor polymorphisms (FokI, BsmI) and breast cancer risk: association replication in two case-control studies within French Canadian population. Endocr Relat Cancer, 15, 975-83.

Tang C, Chen N, Wu M, et al (2009). FokI polymorphism of vitamin D receptor gene contributes to breast cancer susceptibility: a meta-analysis. Breast Cancer Res Treat, 117, 391-9.

Trabert B, Malone KE, Daling JR, et al (2007). Vitamin D receptor polymorphisms and breast cancer risk in a large population-based case control study of Caucasian and African-American women. Breast Cancer Res, 9.

Uitterlinden AG, Fang Y, van Meurs JB, et al (2004). Genetics and biology of vitamin D receptor polymorphisms. Gene, 338, 143-56.

Wang J, He Q, Yu-guo, et al (2013). Associations between vitamin $\mathrm{D}$ receptor polymorphisms and breast cancer risk. Tumor Biol, 34, 3823-30.

Welsh J (2007). Vitamin D and prevention of breast cancer. Acta Pharmacol Sin, 28, 1373-82.

Yang B, Liu S, Yang X, et al (2014). Current evidence on the four polymorphisms of VDR and breast cancer risk in Caucasian women. Meta Gene, 2, 41-49.

Zhang K, Song L (2014). Association between Vitamin D receptor gene polymorphisms and breast cancer risk: a metaanalysis of 39 Studies. PLOS ONE, 9, 96125.

Zhou H, Xu C, Gu M (2009). Vitamin D receptor (VDR) gene polymorphisms and Graves' disease: a meta-analysis. Clin Endocrinol $(O x f), 70,938-45$.

Zinser GM, Welsh JE (2004). Accelerated mammary gland development during pregnancy and delayed postlactational involution in vitamin D3 receptor null mice. Mol Endocrinol,18, 2208-23.
DOI:http://dx.doi.org/10.7314/APJCP.2016.17.2.479

Do VDR Gene Polymorphisms Contribute to Breast Cancer?

Zmuda JM, Cauley JA, Ferell RE, et al (2000). Molecular epidemiology of vitamin D receptor gene variants. Epidemiol Rev, 22, 203-17. 